\title{
Characterization, Treatment, and Recovery of Chemical Species from the Bayer Process' Red Mud Waste
}

\author{
Gabriela Abib \\ Colégio Dante Alighieri, Alameda Fernão Cardim, São Paulo, São Paulo (SP), 01403-020, Brazil.; gabriela.abib@gmail.com
}

\begin{abstract}
Aluminum is an indispensable metal nowadays. It can be used as a raw material for several industrial products. In order to obtain aluminum, it is necessary industrial processing that involves the extraction of bauxite ore, its refining, and the consequent obtaining of alumina, that is later converted into metallic aluminum. In addition to producing alumina, the process generates a significant amount of a waste called "red mud", which represents a challenge for the industries that need to dispose it without harming the environment. Therefore, this study's main objective was to characterize a sample of red mud from Companhia Brasileira do Alumínio (CBA). The residue was characterized in terms of chemical composition, mineralogical composition, as well as leaching and solubilization ablities. The waste showed a predominance of the following compounds: $\mathrm{Fe} 2 \mathrm{O} 3, \mathrm{Al} 2 \mathrm{O} 3$ and $\mathrm{SiO} 2$. In the solubilization test, the sample presented a concentration of some elements above the limit allowed by environmental standards. In the leaching test, all parameters were below the standard's limits. In the red mud treatment stage, the alkalinity was successfully removed after three washes with distilled water. The subsequent steps of iron and aluminum recovery, and separation of the rare earth elements will be carried out.

KEYWORDS: Chemistry; Environmental Chemistry; Red Mud; Materials Characterization; Recovery and Recycling.
\end{abstract}

\section{Introduction}

Aluminum is the third most abundant chemical element on planet Earth. ${ }^{1}$ It is a bright, malleable, resistant metal with multiple uses. The production of this material is indispensable in today's age as it can be used as raw material for several industrial products, including food and beverage packaging, car wheels, building materials, aircraft and cell phones parts, pans, wheelchairs, benches, stairs, chairs, etc. As it has several applications, aluminum production is gradually increasing worldwide. However, to obtain aluminum as a final product, solid waste is generated, which, if not treated or disposed of properly, can lead to severe environmental problems.

Industrial processing is necessary to obtain aluminum. It involves the extraction of bauxite ore, its refining through the Bayer Process, and the consequent obtaining of alumina $\left(\mathrm{Al}_{2} \mathrm{O}_{3}\right)$. Later on, the alumina is converted into metallic aluminum. However, the Bayer Process, in addition to producing alumina, also generates a significant amount of a waste called red mud (RM). RM represents a considerable problem for the refining industries, because of the harm that its inappropriate disposal can cause to the environment. Usually, the red mud is placed in dams (Figure 1). However, this type of structure represents a risk due to the possibility of rupture. This kind of accident has already happened in Brazil in Mariana city in 2015 and Brumadinho city in 2019.

Brazil has a series of laws, which contains rules to prevent and reduce the generation of waste in the country. It also encourages the reuse of solid waste that has economic value and can be recycled. Also, this measure establishes the appropriate environmental disposal of waste that cannot be recycled or reused. $^{2}$

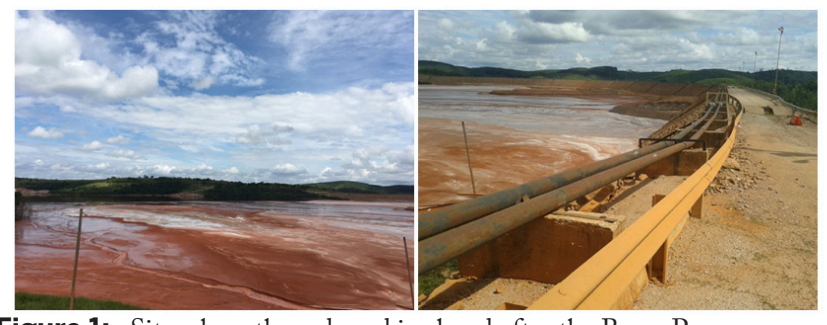

Figure 1: : Site where the red mud is placed after the Bayer Process.

The red mud generated in the Bayer Process is an insoluble residue composed of aluminum hydroxides, iron oxides and hydroxides, kaolinite or halloysite, titanium oxide, and other elements. ${ }^{3}$ This waste is classified as highly corrosive by the Associação Brasileira de Normas Técnicas (ABNT).

Some researchers have studied applications for red mud, such as adding it to the composition of ceramic materials, the manufacture of cement, bricks, and using it for alkalinizing acid soils, etc. However, these studies do not have large-scale applications, and therefore, the waste generated is not fully used. Besides, these uses do not lead to enough profit to attract the attention of pertinent companies. ${ }^{4}$

For a long time, red mud was considered an unusable waste for the aluminum industry. However, economic expenditures and environmental threats related to the disposal of this waste have encouraged companies and scientists to search for more environmentally safer options, which provide a reduction in the amount of RM destined for dams.

Research aimed at recovering iron, titanium, and other metals have been developed. Generally, the studies presented in the literature are not financially viable. ${ }^{4}$ However, if the recovery of 
more valuable elements, such as lanthanum and cerium, which are rare earth elements, become possible, the commercialization of these products can most likely cover the costs for the treatment of the mud, making the process viable from an economic point of view.

The rare earth elements are essential chemical elements for the production of catalysts, magnets, luminescent materials, among other products. Annually, their consumption around the world reaches approximately 150 thousand tons. ${ }^{5}$

Currently, China has a global monopoly in the production and sale of rare Earth elements, earning about 5.7 billion dollars a year and administrating $95 \%$ of the worldwide reserves. Many companies fear an increase in the prices of rare earth elements, as it had already occurred in 2010, when these compounds reached the highest level so far, and there are no other alternative resources to replace their functions by industry. ${ }^{6}$

Although these components are in abundance on earth's crust, they are complicated to extract, leading their prices to be increased on the world market. ${ }^{6}$ Therefore, developing a process in stages to recover valuable resources from the RM can be an exciting alternative for companies that produce aluminum to generate profit and make the disposal of this residue less hazardous for the environment.

The main objective of this research is to analyze red mud and develop a method to recover a considerable number of compounds and chemical elements, including producing an alkaline solution of $\mathrm{NaOH}, \mathrm{Fe}, \mathrm{Al}, \mathrm{La}$, and $\mathrm{Ce}$, from it. Hence, the companies that generate this residue can reduce its quantity and furthermore grow economically.

\section{- Methods \\ Sample collection}

A sample of the red mud was collected in February 2018 at Companhia Brasileira de Alumínio, which uses the Bayer Process to obtain alumina. CBA is located in the city of Alumínio, close to São Paulo city, in Brazil.

The red sludge is generated in a step called "Sludge Filtration." In this stage, the waste is separated from the process with a filter.

Chemical, morphological and environmental characterization of the waste:

The collected red mud was characterized in terms of chemical composition by X-ray fluorescence analysis (Table 1). The equipment used was the PANalytical X-ray fluorescence spectrometer, model Zetium. The Loss on Ignition (LOI) was carried out at $1,020{ }^{\circ} \mathrm{C}$ for two hours.

The morphology of the RM residue was verified in a Scanning Electron Microscope model Philips XL-30, using increments of 250 and $1500 \mathrm{x}$ at $15 \mathrm{kV}$ (Figure 2). The samples were placed on a support and covered with a thin layer of gold to make them conductive before being subjected to the microscope. Leaching and solubilization tests were performed according to the Brazilian law standards, called "Associação Brasileira de Normas Técnicas" - ABNT (Tables 2 and 3).

\section{Alkalinity Removal:}

The experimental part of this stage was performed at the chemistry laboratory of the Dante Alighieri high school. First, the $\mathrm{RM}$ was dried at $1050^{\circ} \mathrm{C}$ in an oven at night (Figure 3 ). the $\mathrm{pH}$ of the mixture was retested. Then, again, the residue was stirred for 30 minutes followed by rest intervals of $15 \mathrm{~min}$ utes. The $\mathrm{pH}$ measurements were performed two more times so that the $\mathrm{pH}$ variability could be verified.

Table 1: : Chemical analysis of the red mud.

\begin{tabular}{|c|c|}
\hline Component & Content \% \\
\hline $\mathrm{Fe}_{2} \mathrm{O}_{3}$ & 30.3 \\
\hline $\mathrm{Al}_{2} \mathrm{O}_{3}$ & 22.0 \\
\hline $\mathrm{SiO}_{2}$ & 15.4 \\
\hline $\mathrm{Na}_{2} \mathrm{O}$ & 8.57 \\
\hline $\mathrm{CaO}$ & 4.96 \\
\hline $\mathrm{TiO}_{2}$ & 3.03 \\
\hline $\mathrm{SO}_{3}$ & 0.90 \\
\hline $\mathrm{P}_{2} \mathrm{O}_{5}$ & 0.62 \\
\hline $\mathrm{PbO}$ & 0.17 \\
\hline $\mathrm{K}_{2} \mathrm{O}$ & 0.16 \\
\hline $\mathrm{Cl}$ & 0.15 \\
\hline $\mathrm{ZrO}_{2}$ & 0.15 \\
\hline $\mathrm{ZnO}$ & 0.13 \\
\hline $\mathrm{MgO}$ & 0.11 \\
\hline $\mathrm{MnO}$ & 0.09 \\
\hline $\mathrm{Cr}_{2} \mathrm{O}_{3}$ & 0.05 \\
\hline $\mathrm{CeO}_{2}$ & 0.04 \\
\hline $\mathrm{CuO}$ & 0.03 \\
\hline SrO & 0.03 \\
\hline $\mathrm{BaO}$ & 0.03 \\
\hline $\mathrm{La}_{2} \mathrm{O}_{3}$ & 0.02 \\
\hline $\mathrm{Nb}_{2} \mathrm{O}_{5}$ & $<0.01$ \\
\hline LOI & 13.0 \\
\hline
\end{tabular}

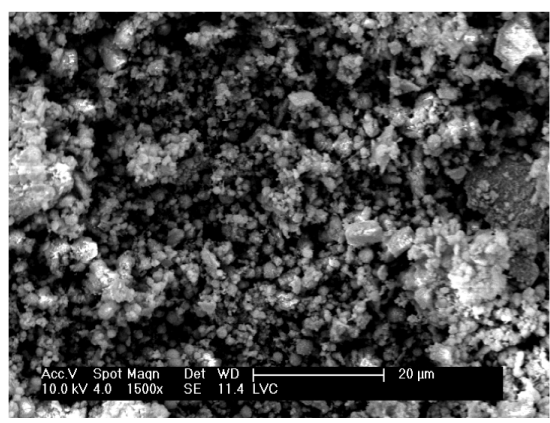

Figure 2: : The morphology of the RM residue verified in a Scanning Electron Microscope, using increments of 1500X.

Table 2: Leached extract of RM

\begin{tabular}{|l|l|l|l|}
\hline \multicolumn{1}{|c|}{ Parameter (mg/L) } & $\begin{array}{c}\text { Limits for } \\
\text { Quantification (LQ) }\end{array}$ & \multicolumn{1}{|c|}{ Results } & \multicolumn{1}{c|}{$\begin{array}{c}\text { Brazilian law } \\
\text { standards }\end{array}$} \\
\hline Total of Arsenic & 0.010 & $<\mathrm{LQ}$ & 1.000 \\
\hline Total of Barium & 0.010 & $<\mathrm{LQ}$ & 70.000 \\
\hline Total of Cadmium & 0.005 & $<\mathrm{LQ}$ & 0.500 \\
\hline Total of Lead & 0.01 & $<\mathrm{LQ}$ & 1.00 \\
\hline Chromium & 0.010 & 0.154 & 5.000 \\
\hline Fluorine & 0.10 & $<\mathrm{LQ}$ & 150.00 \\
\hline Total of Silver & 0.010 & $<\mathrm{LQ}$ & 5.000 \\
\hline Total of Selenium & 0.010 & $<\mathrm{LQ}$ & 1.000 \\
\hline Total of Mercury & 0.00100 & $<\mathrm{LQ}$ & 0.10000 \\
\hline
\end{tabular}


Table 3: Solubilized extract of RM.

\begin{tabular}{|l|l|l|l|}
\hline \multicolumn{1}{|c|}{ Parameter (mg/L) } & $\begin{array}{c}\text { Limits for } \\
\text { Quantification (LQ) }\end{array}$ & \multicolumn{1}{|c|}{$\begin{array}{c}\text { Brazilian law } \\
\text { standards }\end{array}$} \\
\hline Total of Aluminium & 0.010 & 287.600 & 0.200 \\
\hline Total of Arsenic & 0.010 & $<\mathrm{LQ}$ & 0.010 \\
\hline Total of Barium & 0.010 & $<\mathrm{LQ}$ & 0.700 \\
\hline Total of Cadmium & 0.005 & $<\mathrm{LQ}$ & 0.005 \\
\hline Total of Lead & 0.010 & $<\mathrm{LQ}$ & 0.010 \\
\hline Total of Cyanide & 0.005 & 0.009 & 0.070 \\
\hline Chloride & 0.50 & 23.17 & 250.00 \\
\hline Total of Copper & 0.010 & $<\mathrm{LQ}$ & 2.000 \\
\hline Total of Chromium & 0.010 & 0.758 & 0.050 \\
\hline Total of Iron & 0.010 & $<\mathrm{LQ}$ & 0.300 \\
\hline Fluoride & 0.10 & $<\mathrm{LQ}$ & 0.80 \\
\hline Phenol Index & 0.03 & 0.59 & 0.01 \\
\hline Total of Manganese & 0.010 & $<\mathrm{LQ}$ & 0.100 \\
\hline Nitrate & 0.11 & $<\mathrm{LQ}$ & 10.00 \\
\hline Total of Silver & 0.010 & $<\mathrm{LQ}$ & 0.050 \\
\hline Total of Selenium & 0.010 & $<\mathrm{LQ}$ & 0.010 \\
\hline Total of Sodium & 1.00 & 1470.00 & 200.00 \\
\hline Sulfate & 0.50 & 36.95 & 250.00 \\
\hline Surfactants & 0.10 & 1.06 & 0.50 \\
\hline Total of Zinc & 0.010 & $<\mathrm{LQ}$ & 5.000 \\
\hline Total of Mercury & 0.00100 & $<\mathrm{LQ}$ & 0.00100 \\
\hline & & & \\
\hline
\end{tabular}

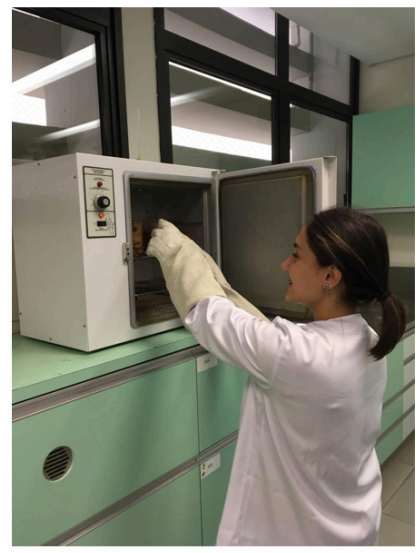

Figure 3: Sample being subjected to a muffle.

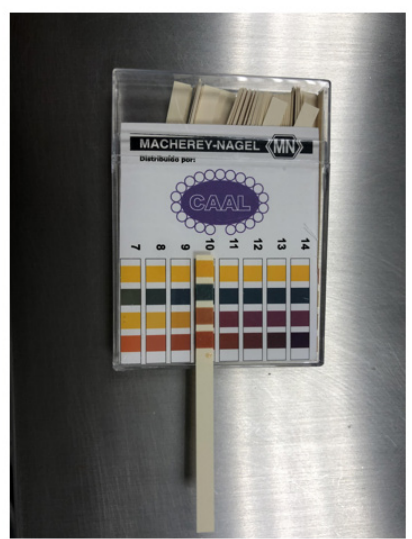

Figure 4: $\mathrm{PH}$ universal indicator.

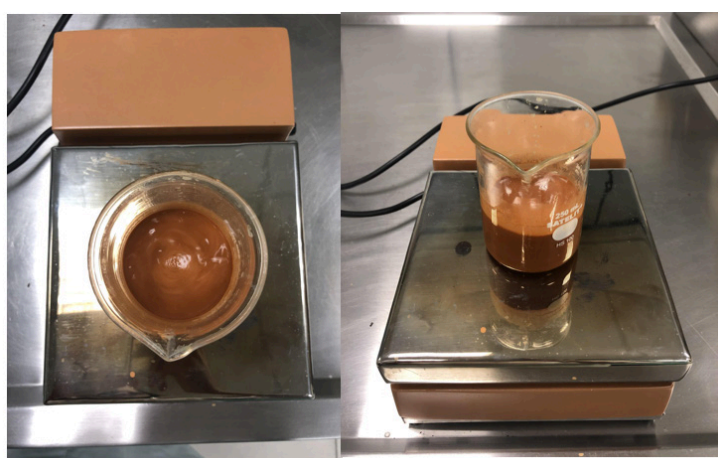

Figure 5: Samples being agitating.

After these steps, the residue was filtered through a beaker with filter paper and funnel (Figure 6). The sludge was subjected to a drying process at $105^{\circ} \mathrm{C}$, and its mass was determined on an analytical balance. After weighing, the sample was heated in a furnace for one hour at $600{ }^{\circ} \mathrm{C}$.

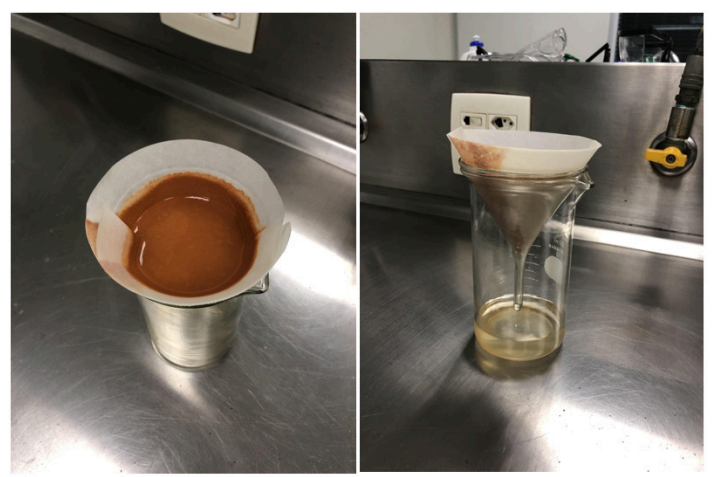

Figure 6: Residue being filtered through a beaker with filter paper and funnel.

\section{Iron removal:}

The methodology for this step was carried out at the Dante Alighieri high school laboratory, and the parameters used were adapted from the literature according to Aguirre and Diaz. ${ }^{7}$ First, calculations to define the molar concentration of sulfuric acid were done. Thus, approximately $20 \mathrm{~mL}$ of diluted sulfuric acid (already prepared), was added to a $100 \mathrm{~mL}$ beaker containing $4 \mathrm{~g}$ of heavy calcined red mud powder on a precision scale.

The mixture was subjected to a magnetic stirrer previously heated to $80^{\circ} \mathrm{C}$ for 1 hour. During that process, it was noted the release of gas and the clarification of the mixture (Figure 7). After stirring, the suspension was filtered (Figure 8). The methodology flowchart is summarized in Figure 9.

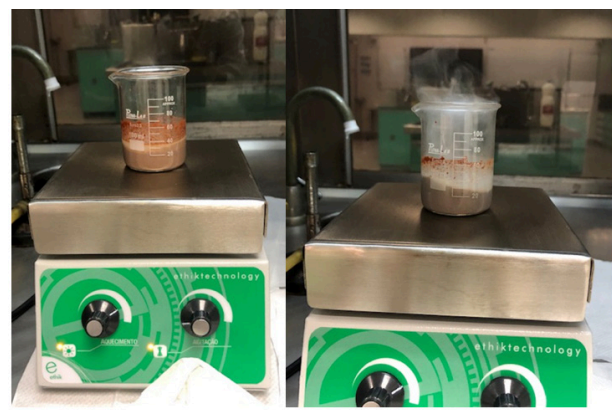

Figure 7: Red mud in a magnetic stirrer being heated. 


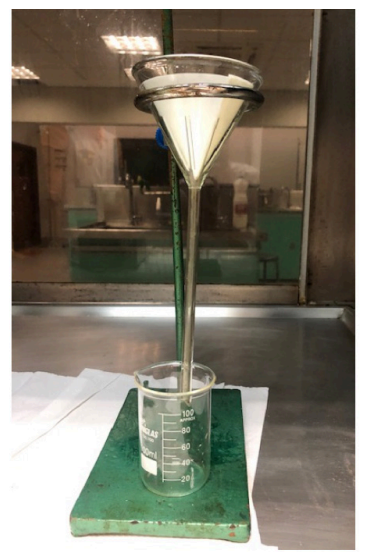

Figure 8: Filtration system.

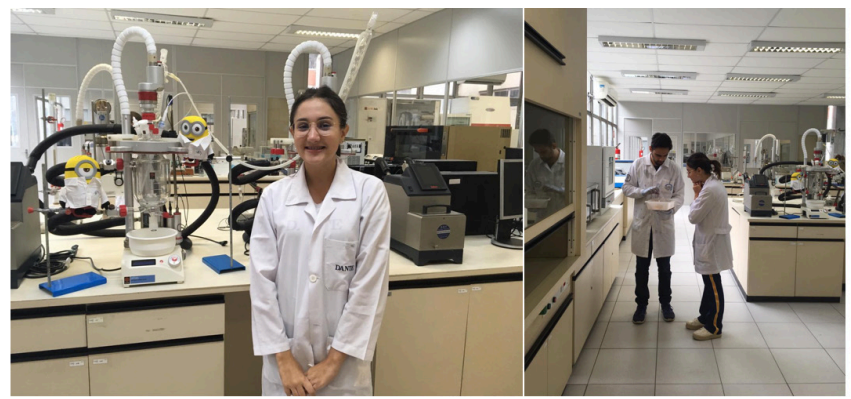

Figure 9: Photographs taken at the Laboratório de Reciclagem, Tratamento de Resíduos e Extração (LAREX).

\section{Alkalinity removal:}

The initial $\mathrm{pH}$ of the laboratory distilled water was 6 . The first step was adding $100 \mathrm{~mL}$ of water to the alkaline RM, then the suspension went to the magnetic stirrer. Later on, the mixture was left to rest. The $\mathrm{pH}$ of the water measured was 10 . In the subsequent stirring, there was no change in $\mathrm{pH}$, which remained at 10 .

The sample mass, after the wash, was $9.4 \mathrm{~g}$, and the volume of the filtered solution, $80 \mathrm{~mL}$. The $\mathrm{pH}$ of the duplicate wash water was 10 . The mass of RM after the removal of alkalinity was $9.35 \mathrm{~g}$, and the volume of the filtered solution, $75 \mathrm{~mL}$. Therefore, the alkalinity removal step was valid since the red mud washing water reached $\mathrm{pH} 10$.

\section{- Results and Discussion Alkalinity removal:}

As shown in Table 1, the red mud has a predominance of the following elements: $\mathrm{Fe}_{2} \mathrm{O}_{3}, \mathrm{Al}_{2} \mathrm{O}_{3}, \mathrm{SiO}_{2}, \mathrm{Na}_{2} \mathrm{O}, \mathrm{CaO}$, and $\mathrm{TiO}_{2}$. This result is similar other authors characterization. ${ }^{4,8,10}$

Figure 2 shows the residue morphology by scanning electron microscopy, with a $1500 \mathrm{X}$ magnification. The compounds in red mud have different sizes and shapes.

The results of the leaching and solubilization tests are shown in Tables 2 and 3, respectively. The ABNT standard defines leaching as the process for determining the transfer capacity of organic and inorganic substances present in solid waste (ABNT, 2004). The waste is classified according to its behavior in contact with a solvent. It can be classified as hazardous or non-hazardous waste. In the leaching test (Table 2), all parameters were below the limits defined by the law
(ABNT NBR 10005: 2004 standard), therefore the waste is classified as non-hazardous.

From the analysis of the solubilization test (Table 3), it can be concluded that some of the sample elements show a concentration above the required limit: total aluminum, total chromium, phenol, and total surfactants. Therefore, the waste is classified as non-inert.

According to the ABNT Standard, hazardous wastes are classified into class I, while non-hazardous wastes are in class II. Non-hazardous waste can also be classified into two subtypes: class II A (non-inert) or class II B (inert). Therefore, the red mud is classified as class IIA.

\section{Red Mud Treatment:}

At this stage of the project, we explored a proposal for the treatment of red mud that aimed to recover compounds present in it. According to several studies, rare earth metals are usually extracted from another compound using acidic solutions, such as sulfuric and hydrochloric acids., ${ }^{4,7}$ The red mud is alkaline and, therefore, this alkalinity could hinder the extraction of rare earth metals. Consequently, the alkalinity of the residue should be the first to be removed. The alkaline solution could return to the Bayer Process, as it is one of the raw materials used in this process.

Because the red mud has a high content of the elements iron and aluminum oxides (as shown in Table 1, with percentages of $30.3 \%$ and $22.0 \%$, respectively), the next steps should be the extraction of these two elements. The recovered iron can be sold, and the aluminum oxide returned to the Bayer process. After these initial stages, the final step is the extraction of rare earth metals, which are rated with a high commercial value.

\section{Conclusion}

The red mud remaining from the Bayer process presented $\mathrm{Fe}_{2} \mathrm{O}_{3}, \mathrm{Al}_{2} \mathrm{O}_{3}, \mathrm{SiO}_{2}, \mathrm{Na}_{2} \mathrm{O}, \mathrm{CaO}$, and $\mathrm{TiO}_{2}$ as main components. In the solubilization test, the sample showed a concentration of aluminum, chromium, phenol, sodium, and surfactants above the standard. In the leaching test, all parameters were below the limits defined by the Brazilian standard for residues. Therefore, the red mud was classified as class IIA waste.

The alkalinity removal of the red mud was successfully performed after three washes with distilled water. However, the subsequent steps of iron recovery, extraction of aluminum, and separation of rare earths present in the waste will still be carried out. This part of the methodology was not executed in 2020 due to restricted access in the laboratories of Dante Alighieri High School.

The next steps of this study will be to carry out the experimental part pending in the partner laboratory of the project (LAREX - USP) and to present this proposal for the recovery of resources for the company that generates red mud.

\section{Acknowledgements}

I would like to thank the Laboratório de Reciclagem, Tratamento de Resíduos e Extração (LAREX), located at the Polytechnic School of the University of São Paulo, and Mr. Amilton Botelho for his assistance in carrying out the exper 
iments related to the characterization of the red mud sample. Also, I am extremely grateful for my mentor professor Juliana Izidoro for always supporting me and providing me feedback regarding my project.

\section{References}

1. Hydro. "Ciclo de vida do alumínio", 2019. <https://www. hydro.com/pt-BR/a-hydro-no-brasil/Sobre-o- aluminio/> (accessed April 27, 2018).

2. Ministério do Meio Ambiente - MME < http://www.mma. gov.br/> (accessed April 27, 2018).

3. M. L. P. Antunes; F. T. da Conceição; G. R. B. Navarro.

"Caracterização da Lama Vermelha Brasileira (Resíduo do

Refino da Bauxita) e Avaliação de suas Propriedades para

Futuras Aplicações", 2011.“CLEANER PRODUCTION

INITIATIVES AND CHALLENGES FOR A

SUSTAINABLE WORLD”, volume 3, pp. 1-10

(accessed May 17, 2019).

4. Silva Filho, E. B.; Alves , M. C. M.; Da Motta. "Lama vermelha da indústria de beneficiamento de alumina: produção, características, disposição e aplicações alternativas", 2006. Revista Matéria, v. 12, n. 2, pp. 322 - 338, 2007. Revista Matéria. <Red mud: an environmental problem in alumina industry $>$ (Accessed Oct 21, 2020).

5. Janaína Simões. "Brasil tem uma das maiores reservas de terras raras do planeta”, 2011. <https://www.crq4.org.br/ quimicaviva_terrasraras $>$.(accessed April 5, 2019).

6. Jonas Gonçalves. “Terras raras”, 2013. <https://www.crq4.org. br/quimicaviva_terrasraras> (accessed Dec 8, 2019).

7. Marcos Aguirre; Samuel Aguirre Diaz. "Processo integrado para a recuperação dos metais da lama vermelha”, 2013. <https://www.escavador.com/patentes/221416/processointegrado-para-a-recuperacao-dos-metais-da-lamavermelha> (accessed Jul 11, 2018).

8. Alan Rabelo de Souza Moura; Emílio Henrique Ferreira; Felipe Kiyoshi Fukushima; Teodoro Macedo Araújo Neto; Thalita Maria Pontes Moutinho; Thiago Valente da Costa. "Processo de obtenção do alumínio", 2008. Belém: Universidade Federal do Pará (accessed April 26, 2019).

9. M. L. P. Antunes; F. T. da Conceição; S. P.Toledo; P. K. Kiyohara. "Bauxita e seu resíduo, caracterização e estudo por microscopia eletrônica”, 2012. 56 Congresso Brasileiro de Cerâmica. $1^{\circ}$ Congresso Latino-Americano de Cerâmica (accessed April 5, 2019).

10. A.B., Botelho Junior, D.C.R., Espinosa, and J.A.S, Tenório. "Characterization of Bauxite Residue from a Press Filter System: Comparative Study and Challenges for Scandium Extraction.” Mining, Metallurgy \& Exploration (2020). https://doi.org/10.1007/s42461-020-00333-3

(accessed Dec 18, 2020).

\section{- Author}

Gabriela Abib is a senior student at Dante Alighieri High School. She started getting involved in science programs throughout her freshman year. She plans to use the knowledge that she has learned at the scientific program in her future $\mathrm{ca}^{-}$ reer as well as applying it to the Circular Economy area. 